\title{
Managing and preparing for emerging infectious diseases- avoiding a catastrophe
}

\begin{tabular}{|r|l|}
\hline Journal: & Academy of Management Perspectives \\
\hline Manuscript ID & AMP-2019-0023.R3 \\
\hline Document Type: & Article \\
\hline Research Methods: & $\begin{array}{l}\text { Systematic review < Qualitative Methods, Text/content analysis < } \\
\text { Qualitative Methods }\end{array}$ \\
\hline Theoretical Perspectives: & Resource dependence, Resource-based view, Sensemaking \\
\hline Disciplinary Domains: & $\begin{array}{l}\text { Alliances and/or networks < Business Policy and Strategy, Business } \\
\text { models < Business Policy and Strategy, Mergers and acquisitions < } \\
\text { Strategy, Crisis and issue management < Business, Society and Ethics }\end{array}$ \\
\hline &
\end{tabular}




\title{
Managing and preparing for emerging infectious diseases - A multi- stakeholder strategic partnership approach towards avoiding a catastrophe
}

\begin{abstract}
The extent and impact of neglected diseases has been well documented in the public health and medical science literature. However, from a strategic management and organizational perspective, there is a gap in first, identifying the key stakeholders and second, understanding the complex relationships that underpin the functioning of Product Development Partnerships (PDPs). The PDPs are a type of public private partnerships (PPPs) in the global health system that are specifically formed to address the challenge of lack of new drugs for such diseases. PDPs act as strategic system integrators and in that role they facilitate smooth and successful actions of key stakeholders in the context of managing the drug development process to address neglected and emerging infectious diseases. It is against this backdrop, that this paper focuses to (a) identify the importance and relevance of PDPs in the development of new drugs for neglected and emerging infectious diseases; and (b) identify the key stakeholders, their relationships and (levels) of dependencies in PDPs. In the process we further contribute by developing a model that illustrates the complex interrelationships between these stakeholders that governs the potential success of fighting emerging infectious diseases. Our model offers a unique perspective to the strategic alliance literature by not only showing the complex interrelationships between the various stakeholders at the global level but also in highlighting various capabilities required in overcoming challenges. These are identified to include managing power, trust and governance challenges. Theoretically, we utilize the resource dependency lens to develop our model, arguing that PDPs become dependent on the external resources (stakeholder actions) and that such resources are key to organisational success as access and control over these stakeholder actions is a basis for greater success. Based on our extensive analysis of the literature and the contextualisation of the recent Novel Coronavirus epidemic as a case we offer conclusions and reflections on the ability of PDPs to mitigate risks related to neglected and emerging infectious diseases from a management perspective.
\end{abstract}




\section{Introduction}

The evolving pandemic of the Novel Coronavirus is an illustration of the consequences of lack of effective drugs leading to catastrophic consequences. The World Health Organisation (WHO) identifies antimicrobial resistance as one of the greatest threats to global health, and if not taken care of, could lead to medical catastrophe. The resistance to existing classes of antibiotics and greater incidences of emerging infectious diseases necessitates the need for faster development of new and effective drugs (Global Risk Report, 2018; Yang et al., 2018; Nambiar et al., 2014; Zorzet, 2014; Silver, 2011; Hsueh et al., 2005). In this context, public private partnerships (PPPs) are considered crucial in addressing the challenges in the development of new drugs, particularly for neglected and emerging infectious diseases (Varda et al., 2012; Vecchi and Hellowell, 2018). Although PPPs are not a new phenomenon (see Watts, 2016), these arrangements gained momentum in the context of global health system in 1993 following the call from the World Health Assembly to the WHO to mobilize and encourage support from various partners in global health system. As a result, the WHO incorporated 'partnering' as one of the core functions to address global health challenges (see Buse and Waxman, 2001).

In the global health sector, PPPs are collaborative relationships that involve a wide range of actors and stakeholders, including governmental agencies and intragovernmental organizations (as public actors) and research institutes, commercial pharmaceutical companies and professional (as private actors). de Vrueh and Commelin (2017) identify two different types of PPPs in the context of global health sector. The first is known as Product Development Partnerships (PDPs), that are formed to develop pharmaceutical solutions for low and middle income countries; whereas the second type of PPPs, known as 'pre-competitive PPPs', are formed to generate novel scientific concepts (e.g. disease targets) and infrastructure (e.g. databases) by pooling of complementary expertise and knowledge, and sharing of rewards. Apart from these two types, another type of PPP exists in the form of 'access partnerships', which are formed to exclusively focus on delivery of existing technologies or health service delivery (Grace \& Britain, 2010).

Notwithstanding the increasing formation of PPPs in general and PDPs in particular and their significance in the global health system, there is a gap in the strategic management and organisational literature on the phenomenon. In fact, issues pertaining to functioning of PPPs and PDPs have attracted negligible attention in this field. We concur with the assertions by many public health scholars that PDPs are a critical mechanism to address deficiency of necessary drugs for many diseases, particularly neglected diseases and ones that affect the 
poorest countries the most (Ridley, 2001; Widdus, 2001; Mahmoud et al., 2006; Moran, 2005; Munoz et al., 2015). Hence, the success of PDPs are central to avoid a catastrophic 'doomsday scenario'. It is under this backdrop that we argue more research is needed to develop better insight on the relationships between various actors and their overall functioning. Thus, exploring, examining and understanding these arrangements is central to avoiding a catastrophe, which essentially requires a multi-stakeholder approach towards addressing emerging infectious diseases.

Therefore, the focus of this paper is to identify the importance and relevance of PDPs, as a hybridised form of PPPs, in the discovery and delivery of new drugs for emerging infectious diseases towards avoiding a catastrophe. Based on our identification and investigation of the main actors involved in PDPs and their roles and partnerships, we develop a model, utilising the resource dependency theory as a lens that illustrates the complex interrelationships (and dependency) that governs the potential success of fighting emerging infectious diseases. We contribute to the management literature by identifying previous PDPs and formation of existing PDPs in relation to the recent outbreak of the Novel Coronavirus. Our model delineates the complex nature of relationships between various set of actors involved in the functioning of the PDPs. In this respect, it adds to the strategic alliance and outsourcing/subcontracting literature in the sense that it highlights three underlying dimensions that are all based on trust, power-sharing and appropriate incentive structures, and governance challenges at the global level.

\section{Historical context of the emergence of PDPs as a hybridised form of PPPs}

The global health system, particularly since the beginning of the millennium has undergone significant changes, primarily to integrate research, development, and delivery of health interventions. Traditional actors who shaped the global health system, notably the WHO, the supranational health organisation and national health ministries of major developed and developing countries, are now joined by non-government organisations, private organisations, philanthropists and in some cases representatives of civil societies. As a consequence, the nature and landscape of the relationship between the old and the new actors have also undergone change, often manifested with the emergence of new norms, expectations, and approaches of interacting and functioning. The WHO describes public-private partnerships for health as "public sector programmes with private sector participation" (WHO, 2015c), a vague definition that allows for many forms, shapes and sizes of PPPs. The image of a contemporary 
PPP is one, wherein a government organization / partner sits at one end of the table, setting the priorities and rules under which private organizations operate (WHO, 2015c). On the other end are private for-profit entities, non-governmental organizations (NGOs), and/or large multistakeholder initiatives such as Roll Back Malaria, the Global Polio Eradication Initiative, the Global Alliance for Vaccines and Immunization (GAVI), and the Global Fund for HIV/AIDS, Tuberculosis and Malaria and (Dare, 2003). Alongside these bilateral (vertical) interactions, multiple stakeholder PPPs have become a common feature (Gustaven and Hanson, 2009; Aerts et al., 2017). The key players within the PPPs in the global health system, include PDPs such as Stop TB, TB Alliance, the global Alliance for Vaccines and Immunization (GAVI), the Global Fund to Fight AIDS, Tuberculosis and Malaria (GFATM) and the Medicines for Malaria Vaccines (MMV), which now occupy centre stage in their respective disease categories have gained legitimacy as they are considered as the most promising form of collectively addressing some of the longstanding challenges in the global health system. It is critical to highlight that increase in the international support for the newer institutions have led to a relative and, in some cases, absolute decline in the financial and structural importance of traditional actors.

A significant number of PDPs emerged in the late 1990s (Nwaka and Ridley, 2003; Munoz et al., 2015) in response to a growing concern of lack of new drugs for so-called neglected diseases or diseases of tropical countries and public outrage directed at the big pharmaceutical companies due to their lack of interest in developing new solution for these diseases that predominantly affect people in low- and medium-income countries. Interestingly, the historical move towards PDPs could be traced to the creation of the United Nations Development Programme/World Bank/WHO special programme for Research and Training in Tropical Diseases (WHO-TDR) in 1975. WHO-TDR was an effort to enable a partnershiporiented approach to drug development by bringing private and for profit companies on board (Lang and Greenwood, 2003). At that point in time, although some public sector organisations in different countries had taken an interest in developing solutions for different disease categories, only a handful, including the Walter Reed US Army Institute for Research (WRAIR) and Central Drug Research Institute (CDRI) in India, focused on establishing their own drug development infrastructure (see of instance, Nwaka and Ridley, 2003). Also critical to emphasise here that by late 1980 s, most of the pharmaceutical companies had gradually disengaged from developing new drugs for tropical diseases, primarily due to lack of health insurance system and reduced ability of the users in these countries to afford and pay for the 
drugs (Aerts et al., 2017). Lang \& Greenwood (2003) also suggest that the tension between the WHO and the pharmaceutical companies to make drugs accessible at affordable prices, also contributed to the decision of the pharmaceutical companies to withdraw from undertaking R\&D activities for neglected diseases (also see Patnaik, 2011). As a direct result between 1975 and 1999, only 13 new drugs were developed for neglected diseases and almost all the new drugs were essentially either combinations or extensions of existing drugs (Troullier et al., 2002; Craft 2008; Veenken and Pecoul, 2000).

Overuse of existing drugs, particularly in the absence of new options, resulted in a situation wherein the existing drugs became resistant and ineffective thus creating conditions for epidemics particularly malaria and HIV - Aids. Growing epidemics, lack of availability of new drugs and public outrage, in the developed countries towards disengaged pharmaceutical companies and global health institutions provided the context for deliberation at the 1993 World Health Assembly that opened the doors for public private initiatives in the global health system.

\section{Roles and features of the PDPs and identification of key actors}

Traditionally, the central actors for neglected and emerging diseases were most notably the WHO and national health ministries. Since the early millennium, this arrangement has undergone change with greater involvement of an ever-greater variety of civil society and nongovernmental organizations, private firms, and private philanthropists. New partnerships such as WHO's Roll Back Malaria Partnership (RBM), which was formed as a partnership between UN agencies in 1998 and PDPs such as the Stop TB, the Global Alliance for Vaccines and Immunization (GAVI), the Global Fund to Fight AIDS, Tuberculosis and Malaria (GFATM) and Medicines for Malaria Ventures (MMVs) and DNDi have come to exist alongside and somewhat independently of traditional intergovernmental arrangements between sovereign states and UN bodies.

The first two PDPs, namely the International AIDS Vaccine Initiative (IAVI) and the Medicines for Malaria Venture (MMV) were established in the late 1990s, with the support from the Rockefeller Foundation and the WHO Special Programme for Research and Training in Tropical Diseases (WHO/TRD) along with UNDP and the World Bank. The Bill \& Melinda Gates Foundation (BMGF) and the Rockefeller Foundation have played central role in setting up a number of other PDPs, such as the Global Alliance for Tuberculosis Drug Development 
(TB Alliance), the International Partnership for Microbicides (IPM) and the Paediatric Dengue Vaccine Initiative (PDVI). In 1999, Médecins Sans Frontières (MSF), was awarded the Nobel Peace Prize in 1999, committed the Nobel Peace Prize fund to setting up a working group on innovation \& access, which in 2003 led to the creation of DND $i$ with five public sector institutions from endemic countries, including India, Brazil, Malaysia and Kenya and the UNDP/World Bank / WHO's Special Programme for Research and Training in Tropical Diseases (WHO-TDR). Moran (2005) identified approximately 65 neglected disease projects in 2004 and attributes the emergence of PDPs for this spur R\&D activities. Munoz et al., (2015) also highlight the increasing collaborative approach to drug development for neglected diseases and note that more than 300 organizations from the private and public sectors (academic/research institutions, biotechnology companies and other medium and small firms, such as contract research organizations, and large pharmaceutical companies) are engaged in the development of a combined pipeline of 374 drugs and vaccines for 23 neglected diseases (BioVentures for Global Health 2012; also see Pedrique et al., 2013). The PDPs have contributed in the change in R\&D landscape for neglected diseases by, in essence becoming the central organizations for specific diseases and in that role they coordinate communication and coordinational activities with a range of organisations, with varied focus, philosophies, funding sources and business models (Moran et al. 2010; Nwaka and Ridley 2003).

Table 1 exemplifies the three key PDP actors. Examples of other PDP organisations include the International AIDS Vaccine Initiative (IAVI), the Foundation for Innovative New Diagnostics (FIND), and the International Partnership for Microbicides (IPM). Based on table 1 showing the key PDPs operational in the past, we observe rapid formation of PDPs to develop new vaccines for the treatment of the novel Coronavirus. In table 2 we show the varied partnerships being developed at the time of writing this paper. 
Table 1 - Organisational agendas and modus operandi of key PDPs

\begin{tabular}{|c|c|c|c|}
\hline $\begin{array}{l}\text { Product Development } \\
\text { Partnerships (PDPs) }\end{array}$ & Main focus & Funding source & Key roles \\
\hline $\begin{array}{l}\text { The Medicines for } \\
\text { Malaria Venture } \\
\text { (MMV) }\end{array}$ & $\begin{array}{l}\text { Focuses on a single } \\
\text { disease and manages a } \\
\text { vast project portfolio, } \\
\text { from lead generation } \\
\text { through to clinical } \\
\text { development and } \\
\text { regulatory registration. }\end{array}$ & $\begin{array}{l}\text { It receives the } \\
\text { majority of its } \\
\text { funding from the } \\
\text { Gates Foundation }\end{array}$ & $\begin{array}{l}\text {-Plays a key coordinating } \\
\text { role in the global } \\
\text { pharmaceutical effort } \\
\text { against malaria } \\
\text {-Defines the target profiles } \\
\text { of future pharmaceuticals }\end{array}$ \\
\hline $\begin{array}{l}\text { The Drugs for } \\
\text { Neglected Diseases } \\
\text { Initiative (DNDi) }\end{array}$ & $\begin{array}{l}\text {-Maintains a close } \\
\text { relationship with the } \\
\text { humanitarian } \\
\text { nongovernmental } \\
\text { organization (NGO) } \\
\text { Me'decins Sans } \\
\text { Frontie res (MSF) } \\
\text {-Has a vocal stance on } \\
\text { matters of IPRs and } \\
\text { access to medicines }\end{array}$ & $\begin{array}{l}\text { Maintains a policy of } \\
\text { not relying on any } \\
\text { individual donor for } \\
\text { more than } 25 \text { percent } \\
\text { of its budget. In the } \\
\text { United Kingdom, for } \\
\text { instance, product } \\
\text { development } \\
\text { partnerships received } \\
91.8 \text { percent of the } \\
\text { funds allocated by the } \\
\text { Department for } \\
\text { International } \\
\text { Development to } \\
\text { neglected diseases } \\
\text { research in } 2009 .\end{array}$ & $\begin{array}{l}\text { Concentrates on the "most } \\
\text { neglected diseases" i.e. } \\
\text { human African } \\
\text { trypanosomiasis (sleeping } \\
\text { sickness), visceral } \\
\text { leishmaniasis and Chagas }\end{array}$ \\
\hline $\begin{array}{l}\text { The Global Alliance for } \\
\text { Tuberculosis Drug } \\
\text { Development (TB } \\
\text { Alliance) }\end{array}$ & $\begin{array}{l}\text { Focus on a single disease, } \\
\text { but has developed a more } \\
\text { markedly entrepreneurial } \\
\text { profile, adopting traits of a } \\
\text { biotechnology start-up. }\end{array}$ & $\begin{array}{l}\text { Generates a funding } \\
\text { stream independent } \\
\text { of external donors. }\end{array}$ & $\begin{array}{l}\text { Experimented with a } \\
\text { different approach to } \\
\text { Intellectual Property (IP), } \\
\text { creating its own patent } \\
\text { portfolio in order to attract } \\
\text { partners }\end{array}$ \\
\hline
\end{tabular}

Source: (Adapted from Lezaun \& Montgomery, 2015, pp 5-6) 
Table 2 - Key PDP partnerships being created for the Novel Coronavirus epidemic, leading to a possible pandemic.

\begin{tabular}{|c|c|c|c|}
\hline PDP partner 1 & PDP partner 2 & PDP partner 3 & Output \\
\hline $\begin{array}{l}\text { University of } \\
\text { Nebraska Medical } \\
\text { Center (UNMC) in } \\
\text { Omaha, US }\end{array}$ & $\begin{array}{l}\text { National Institute of } \\
\text { Allergy and Infectious } \\
\text { Diseases (NIAID), part } \\
\text { of the National } \\
\text { Institutes of Health } \\
\text { (NIH) }\end{array}$ & $\begin{array}{l}\text { Gilead Science, an } \\
\text { American } \\
\text { biotechnology } \\
\text { company that } \\
\text { researches, develops } \\
\text { and commercializes } \\
\text { drugs. }\end{array}$ & $\begin{array}{l}\text { Manufacturing } \\
\text { antiviral drug } \\
\text { remdesivir for } \\
\text { COVID-19. Initiated a } \\
\text { clinical trial which } \\
\text { was originally } \\
\text { developed to treat } \\
\text { Ebola and in animal } \\
\text { studies showed } \\
\text { promise in treating } \\
\text { SARS and MERS, } \\
\text { which are caused by } \\
\text { coronaviruses. }\end{array}$ \\
\hline $\begin{array}{l}\text { U.S. National Institute } \\
\text { of Allergy and } \\
\text { Infectious Diseases } \\
\text { (NIAID), part of the } \\
\text { National Institutes of } \\
\text { Health (NIH) }\end{array}$ & $\begin{array}{l}\text { Moderna researchers in } \\
\text { collaboration with } \\
\text { scientists at the NIAID } \\
\text { Vaccine Research } \\
\text { Center (VRC). }\end{array}$ & $\begin{array}{l}\text { Funding for the } \\
\text { manufacture of the } \\
\text { batch came from the } \\
\text { Coalition for } \\
\text { Epidemic } \\
\text { Preparedness } \\
\text { Innovations (CEPI). }\end{array}$ & $\begin{array}{l}\text { For the study. mRNA- } \\
1273 \text { is a mRNA } \\
\text { vaccine that encodes } \\
\text { for a prefusion } \\
\text { stabilized form of the } \\
\text { Spike (S) protein. }\end{array}$ \\
\hline $\begin{array}{l}\text { UK-based } \\
\text { GlaxoSmithKline }\end{array}$ & $\begin{array}{l}\text { China-based Clover } \\
\text { Biopharmaceuticals }\end{array}$ & $\begin{array}{l}\text { Government of China } \\
\text { Health Department }\end{array}$ & $\begin{array}{l}\text { To develop a vaccine } \\
\text { candidate for COVID- } \\
19 .\end{array}$ \\
\hline $\begin{array}{l}\text { State-owned } \\
\text { pharmaceutical } \\
\text { companies China } \\
\text { Resources } \\
\text { Pharmaceutical Group }\end{array}$ & $\begin{array}{l}\text { China Medicine Health } \\
\text { Industry Co. }\end{array}$ & $\begin{array}{l}\text { Government of China } \\
\text { Health Department }\end{array}$ & $\begin{array}{l}\text { Speeding production } \\
\text { of chloroquine. This } \\
\text { drug appears to be } \\
\text { effective in treating } \\
\text { the coronavirus with } \\
\text { no severe side effects. } \\
\text { It has been in clinical } \\
\text { use for more than } 70 \\
\text { years. }\end{array}$ \\
\hline $\begin{array}{l}\text { China's National } \\
\text { Medical Products } \\
\text { Administration }\end{array}$ & $\begin{array}{l}\text { Zhejiang Hisun } \\
\text { Pharmaceutical Co., } \\
\text { Ltd. }\end{array}$ & $\begin{array}{l}\text { Government of China } \\
\text { Health Department }\end{array}$ & $\begin{array}{l}\text { Producing large } \\
\text { amounts of } \\
\text { favipiravir, first } \\
\text { antiviral drug } \\
\text { approved to fight } \\
\text { Covid-19 outbreak }\end{array}$ \\
\hline $\begin{array}{l}\text { Paris-based Sanofi's } \\
\text { Sanofi Pasteur, }\end{array}$ & $\begin{array}{l}\text { Biomedical Advanced } \\
\text { Research and } \\
\text { Development } \\
\text { Authority (BARDA), } \\
\text { part of the Office of } \\
\text { the Assistant Secretary } \\
\text { for Preparedness and } \\
\text { Response, US. }\end{array}$ & $\begin{array}{l}\text { U.S. Department of } \\
\text { Health and Human } \\
\text { Services (HHS). }\end{array}$ & $\begin{array}{l}\text { Sanofi plans to } \\
\text { continue investigating } \\
\text { an advanced } \\
\text { preclinical SARS } \\
\text { vaccine candidate that } \\
\text { it had worked on } \\
\text { during the 2002-2003 } \\
\text { SARS outbreak, as it } \\
\text { is similar to the } \\
\text { COVID-19 virus. }\end{array}$ \\
\hline
\end{tabular}




\begin{tabular}{|c|c|c|c|}
\hline $\begin{array}{l}\text { Johnson \& Johnson } \\
\text { Pharmaceuticals, } \\
\text { Headquarters: New } \\
\text { Brunswick, New } \\
\text { Jersey, US. }\end{array}$ & $\begin{array}{l}\text { Biomedical Advanced } \\
\text { Research and } \\
\text { Development } \\
\text { Authority (BARDA), } \\
\text { part of the Office of } \\
\text { the Assistant Secretary } \\
\text { for Preparedness and } \\
\text { Response, US. }\end{array}$ & $\begin{array}{l}\text { U.S. Department of } \\
\text { Health and Human } \\
\text { Services (HHS). }\end{array}$ & $\begin{array}{l}\text { Producing antiviral } \\
\text { drug approved to fight } \\
\text { Covid-19 outbreak } \\
\text { such as favipiravir. }\end{array}$ \\
\hline $\begin{array}{l}\text { Inovio } \\
\text { Pharmaceuticals, an } \\
\text { American } \\
\text { biotechnology } \\
\text { company. }\end{array}$ & $\begin{array}{l}\text { Beijing Advaccine } \\
\text { Biotechnology, a } \\
\text { Chinese group led by } \\
\text { its founder, Emeritus } \\
\text { Professor Bin Wang } \\
\text { from the prestigious } \\
\text { Fudan University and } \\
\text { China's premier DNA } \\
\text { vaccine expert. }\end{array}$ & $\begin{array}{l}\text { Supported by a } \$ 9 \\
\text { million grant from the } \\
\text { Coalition for } \\
\text { Epidemic } \\
\text { Preparedness } \\
\text { Innovations (CEPI). }\end{array}$ & $\begin{array}{l}\text { Inovio has launched } \\
\text { preclinical testing for } \\
\text { clinical product } \\
\text { manufacturing vaccine } \\
\text { INO-4800, against the } \\
\text { coronavirus. }\end{array}$ \\
\hline
\end{tabular}

Source: Various media and pharmaceutical organisation reports

\section{PDPs role as system integrators / facilitators}

Public health scholars conceptualize the creation and functioning of PDPs in the broader context of the medical product / health innovation ecosystem that operates beyond national boundaries (Monuz et al., 2015; Papaioannou et al., 2009). The product development ecosystem includes amongst others, (a) the community of for profit and non-profit organizations, including (bio) pharmaceutical organizations, academic and R\&D; (b) government institutions including national regulatory authorities; and (c) individuals (including public health researcher and scientists and policy-makers in disease-endemic countries and patients) that has an influence on the functioning of the PDPs. In essence, the innovation ecosystem is comprised of multiple actors who are engaged in the production and dissemination of drugs, vaccines and diagnostics for neglected diseases, and it is influenced by external factors particularly pertaining to public health policy, issues relating to financing, regulation and intellectual property apart from human resources and infrastructure. The expert commission under the auspices of the World Health Assembly (WHO, 2006) delineated the following four principles that guide the health innovation ecosystem, and which in essence also provide the overarching guidance to the R\&D activities of the PDPs. The guiding principles are:

- Availability: new product development and adequate supply (quantity) of product

- Acceptability: usability and appropriateness of the product tailored to specific needs

- Quality: product effectiveness, standards for carrying out testing and clinical trials 
- Affordability: ensuring the financing of product development and procurement, affordable prices.

\section{Features of PDPs}

PDPs in this context, function as 'system integrators', in the sense that they facilitate the development of new drugs by integrating / bringing together expertise of different stakeholders in the broader health innovation ecosystem (Munoz et al., 2015). Put simply, at one end, the PDPs, work towards generating funds from key funders, including philanthropic organizations, and on the other hand tap into the knowledge base of partners from academia, public and private sector organisations and various international agencies into long term partnerships to leverage each other's strength towards a common goal of developing a new drug for the focused diseased category. In essence, most PDPs work as virtual non-profit R\&D organizations, essentially possessing technical expertise and provide an oversight in undertaking all product development activities - upstream (research and discovery) and downstream (clinical trials and manufacturing) with different set of partners (Morel et al., 2005; Munoz et al., 2015). Akin to large pharmaceutical companies, PDPs actively manage a portfolio of product development projects and in the process they spread their risk and to increase the chance of success (Grace and Britain (2010). The PDPs have independent scientific-advisory boards, who are responsible for selection of product development projects and selection of partners. Such a selection process is considered as seen as a key advantage, cushioning donors from picking the funding winners/losers and placing that responsibility with those who have better information and expertise with which to make those decisions (Grace and Britain, 2010; Munoz et al., 2015). To summarize, the following are the distinctive features of PDPs:

- PDPs are established as non-profit entities that guarantee them independence and no shareholder expectations of growth and revenue maximization motives;

- The objectives of the PDPs is to develop new medical products that can have a public health impact (specialized, access core to their mission);

- The focus of the PDPs is to develop and enhance 'system integration 'capabilities to engage and leverage diverse resources and capabilities of various actors in the R\&D chain;

- PDPs possess technical expertise to manage a portfolio of R\&D projects; 


\section{Key actors in PDPs, Model Development and Theoretical Lens}

The medical product innovation ecosystem (Munoz et al., 2015) depicts various stakeholders who are involved in the development and delivery of new drugs. In this context, it is critical to highlight that the distinctive features and organisational design of a PDP fundamentally differentiate them from other $R \& D$ focused organisations in the innovation ecosystem.

Since, PDPs operate on a not for profit model, they rely on donor organisations for funding their R\&D projects and operations. Public and philanthropic donors, it is argued, measure return to investment differently than is the case of shareholders in the pharmaceutical industry or venture capitalists in the biotechnology R\&D model (Lezaun \& Montgomery, 2015; Moran et al., 2010; Looney, 2011; Grace \& Britain, 2010). It is considered that philanthropic and public donors do not exert the same pressure as shareholders and venture capitalists and instead they are more interested in facilitating development of the final output - medical products developed to address unmet health needs ${ }^{1}$ (Moran and Stevenson, 2013). Moran et al. (2010) in an analysis of 14 PDPs working in the area of neglected disease R\&D found that almost $49 \%$ of the funding came from one source, namely the Gate Foundation. Munoz et al., (2015) consider 'funding' to be the central enabling factor that underpin the collaborative approach to R\&D that are adopted by the PDPs. In outsourcing and sub-contracting R\&D, the PDPs only have to pay for the services to the scientists involved in the research activities and contract research and manufacturing organisations who undertake other research, clinical trial and basic manufacturing activities. This approach allows the PDPs to reduce the cost of product development. It is in this backdrop Chataway et al., (2007) argue that PDPs also act as brokers amongst numerous private and public sector organizations, by bringing them together in the context of the drug development process. Thus, in essence, PDPs also leverage investments from private partners, particularly larger pharmaceutical companies, in the form of "in- kind" inputs such as pro-bono human resource inputs and access to proprietary molecular libraries (Grace \& Britain, 2010). Considering the importance of funding and its availability, in most cases PDPs have picked up dormant or discontinued research developed elsewhere for product development. In other words, PDPs have and are focusing on the development of repurposed products rather than new chemical entities (NCEs) (Pedrique et al. 2013). The two factors that constrains the capacity of the PDPs to focus on the development of NCEs are: (a) PDPs do not possess either financial muscles and scientific capabilities in house to develop new NCEs and hence on one hand they have to manage their relationships with the funders and on the other

\footnotetext{
${ }^{1}$ See PDP Funders Group (www.pdpfundersgroup.prg)
} 
hand they coordinate developmental work with their operational partners; and (b) the new drugs have to be accessible and affordable to the people who most need those the most (Brooks et al., 2010). Therefore, success for PDPs are not in terms of development of new products rather development of products that are effective and affordable. Hence, the capacity of the PDPs to be effective and successful is underpinned by their capability to manage different relationships, they form with different actors. In the subsequent section, we discuss these relationships, which we argue are central to PDPs existence and functioning by adopting resource dependence perspective.

\section{Discussion}

Theoretically, we utilize the resource dependency theory in bringing together different aspects underpinning the PDP phenomenon. Resource dependency theory is based on the principle that organisations, such as PDPs engage in partnerships, transactions and networks, with other key actors in its environment to access and acquire resources. We posit the view that such 'dependency' on each other's resources create conditions for success at one hand and survival at the other. Resource dependency perspective also sensitises us to adaptations organisations make as they deepen their reliance on other actors. We observe that PDPs as non-profitorganisations are dependent on the one hand on their funders for funding purposes and they are also dependent on the other hand on large and small pharmaceutical and diagnostic and biotechnology companies to undertake research and development of new drugs. We argue that the capacity of PDPs to engage in these two sets of relationships is central to develop new therapeutic solutions for emerging infectious diseases to mitigate risks from these diseases, thus avoiding catastrophic situations. In figure 1, we depict the two sets of relationship between PDPs and the key actors, whose resources, skills and knowledge, the PDPs utilise to develop new drugs. Subsequently, consistent with resource dependence perspective, we analyse the two sets of relationships on the lines of (i) power relations; (ii) trust relations; (iii) governance structures / mechanism. We argue that, these three aspects underpin the relationship between PDPs and their financing and operational partners and hence success and survival of PDPs, inevitably depends on their capacity to manage these nuances. 


\section{Figure 1: PDP Model}

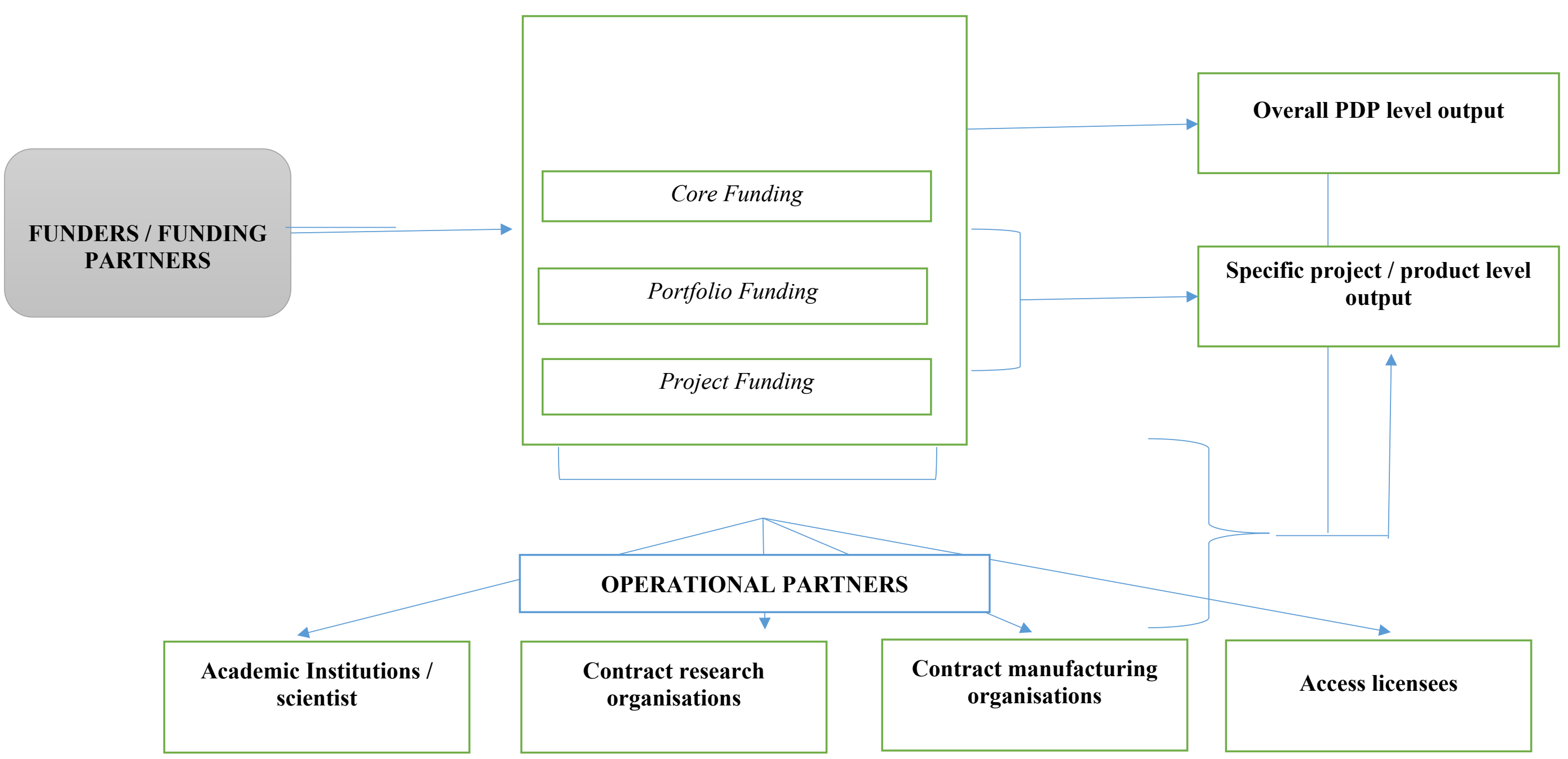




\section{PDPs and relationship with the donors / funders (Power and Trust)}

Moran et al. (2010) identified three categories of donors involved in the global health innovation system. Of the three, the public sector is the most prominent source of funding for the PDPs and contribute more than two third of the total funding and within that category, the public sectors from high income countries and multilateral organizations contribute more than $95 \%$ of that total and the rest is made up of funding from the lower and medium income countries. The philanthropic organizations are the second set of donors, who contribute almost $20 \%$ of the total funding and the bio-pharmaceutical industry, comprising of large and small and medium enterprises contribute the rest. The contributions of these key donors have more or less has remained consistent over the last decade (see for instance Moran et al., 2009; GFinder report, 2018). From the perspective of the PDPs, the source of funding assumes critical. The funding from the government, disbursed through the public sector organizations, is generally given as unrestricted or semi-restricted grants that allows the PDPs to use or allocate between different individual projects depending on the progress the projects make. Also, in some instances, the PDPs use the resources to support capacity building and advocacy work, which is not specifically focused on a particular project rather on overall strategies of the PDP. In contrast, the funding from the private donors, are more restricted in terms of how the funding could be utilised and would need permission from the funder if any changes are made, based on evolving pace of project development (Grace, 2010). Private donors, follow their own approach to evaluate different projects that rely on their funding and in most instances the approach private donors follow is different to the one that PDPs follow and therefore duplication of approaches to review projects complicates the relationship between the private funders and the PDPs.

Resource dependence theory highlight the notion of power relations in the context of resource dependence between organizations (Pfeffer and Salancik, 1978; Hillman et al., 2009). Seen through the lens of PDPs, their functioning and survival, critically depends on their capacity to access financial resources from different sources and in that respect it is imperative that the portfolio of financial resources achieves a balance between unrestricted, semi-restricted and restricted funding (Boulton et al., 2014; Moran et al., 2010). Extant literature highlights that the power relation in the overarching relationship between PDPs and their donors, particularly the private donors, is skewed towards the private funders. Munoz et al., (2015), in highlighting the power yield by donors, particularly in attaching conditions for PDP, note that, "in PDPs, donors decide on the priority areas for funding, the conditions attached to fund disbursements, instruments for control, transparency requirements etc. These requirements are 
not harmonized among PDPs, nor are they made public" (Munoz et al., 2015: 326). The further concur that amongst the different groups of donors, private donors, philanthropic organizations in particular, are most likely to put constraints on how their funding is used and dictate the priorities of the PDPs. Boulton et al. (2014: 36) identified five ways donors impose constraints by limiting the use of funds to:

(a) A specific disease, product area or stage of development;

(b) A group of projects (portfolio funding);

(c) A specific project to the exclusion of all others;

(d) Exact submitted budgets, thus, making any changes or variations needing prior approval; and

(e) A certain timeframe (usually after the signing of a funding agreement and within a specific year).

One of the critical implications of this asymmetric relationship between the donors and the PDPs is that the efforts to develop new drugs and services may actually lead to a situation wherein the products or services developed in the process may not directly affect the disease endemic countries. In other words, the focus of the donors might not be congruent to the needs of the disease endemic countries and as a result the product portfolio of the PDP might not directly contribute to address the needs of the disease endemic countries. Notwithstanding, the imbalance in the power relationship between the PDPs and the donors, particularly the private sector funders, the donors also have to rely on the PDPs to develop effective solutions. Success of PDPs, also legitimise the donors, who are essentially new actors the in the broader gamut of the global health innovation system (Grace, 2010; Moran et al., 2009). This paradoxical relationship, in essence demonstrates the complexities underpinning the global health innovation system and highlights the need for distinctive capabilities of the board members and senior managers of the PDPs to align and manage the focus of the PDP with the interests of the funders, industry partners and the governments in the countries where the needs for the therapeutic solutions are the highest. Put simply, success of PDPs, akin to any dependent entity in an unfavourable exchange relationship, depends on its capacity to absorb constrains as it makes progress to deliver outcomes (Gargiulo, 1993; Casciaro and Piskorski, 2005).

The issues relating to interdependence and power relations, bring to forth two interrelated constructs, namely, (a) governance of the relationship between PDPs and the donors in particular; and (b) trust relationship between the PDPs and the funders. Considering 
the PDPs are not for profit organizations, they aim to keep their costs down. According to Moran et al. (2010), almost 88\% of the funds that the PDPs generate from donors are disbursed to their academic partners, companies undertaking developmental work and other drug development activities. In the process, the PDPs also contribute in developing research and development capacity in disease endemic countries (Grace, 2010; Pratt and Loff, 2012). Thus, the PDPs are organised around being effective and efficient in getting the development of new drugs. Most of the PDPs comprise of small core team, who have experience in public health and pharmaceutical industry and these members, in essence, manage various aspects pertaining to operational aspects of the PDPs including project and portfolio management. The work of the core staffs is overseen by a board and external advisory members, who bring scientific and technical expertise to the PDPs (Moran et al., 2010; Munoz et al., 2014). The board plays a critical role in shaping the overall strategic focus of the PDPs whereas scientific and technical experts provide advice on upstream and downstream activities pertaining to the drug development process. The composition of the board and the involvement of scientific and technical advisors are critical from two perspectives. First, it helps generate competence and capability trust in the PDP. Trust is one of the central themes in inter-organizational relationships (Zaheer and Harris, 2006; Lumineau and Quelin, 2012) that in essence mitigate risks and uncertainty (Rousseau et al., 1998). In a dyadic inter-organizational context, competence trust, pertains to confidence of one partner on the resources and capabilities of the other partner. Although the PDPs lack resources and capabilities of private pharmaceutical companies to undertake research and development activities, the involvement of board members and scientific and technical experts provide donors the confidence that PDP possess intellectual capital and expertise necessary to ensure efficient and effective development of new products (Lynall, Golden, \& Hillman, 2003; Zahra, Filatotchev \& Wright, 2009; Kim \& Cannella, 2008). The second implication of involvement of experienced board and scientific and technical experts pertains to legitimization of the PDPs. Apart from creating conditions for competence trust, involvement of experts also facilitate legitimisation of the PDPs (Boulton et al., 2014; Munoz, et al., 2014).

The evaluation of the relationship between the donors and PDPs generally takes place through evaluation mechanisms. From the perspective of the donors, demonstration of value for money (VfM) is the central rationale that underpin evaluation of PDPs and their activities (see Boulton et al., 2014). VfM, in essence, aims to demonstrate optimal use of donor's resources to achieve the intended outcomes, which essentially pertain to development of new drugs. Although there is a lack of insight on how different donors evaluate their funding, 
Canada's International Development Research Centre's (IDRC) donor partnership division, which engages with multiple donors, evaluate VfM on the basis of the contribution to the three E's:

- Economy: getting the best value

- Efficiency: maximising the outputs for a given level of inputs

- Effectiveness: ensuring that the outputs deliver the desired outcome (IDRC, 2013)

\section{PDPs relationship with operational partners (Governance)}

Most of the PDPs involved in developing new drugs and other solutions for neglected diseases do not possess developmental expertise and hence do not undertake any in-house research or development activities. What in essence, the PDPs possess is intellectual capital and expertise and experience of senior managers involved in overseeing the organization and functioning of the PDPs. Broadly, PDPs comprise of two category of individuals who are critical for their functioning. First, in most PDPs, the core team comprise of experienced individuals possessing background in public health and research and development in the area of neglected diseases. These individuals play the critical role in designing and shaping the strategic orientation, in consultation with the board and advisors, and organizational form of the PDP. Second category of individuals are project managers, who have prior experience of overseeing and managing drug development programmes. Whereas the first category of individuals provides strategic direction to PDPs, scan and identify opportunities in the medical innovation ecosystem and interact work with funders to raise capital to develop new products, the project managers forge and drive the drug discovery and development activities in collaboration with various operational partners in the global health innovation ecosystem. In essence, the role of project managers, is akin to one that that any project managers in (bio) pharmaceutical companies perform.

However, there are two fundamental difference between a (bio) pharmaceutical company and PDP. First, unlike pharmaceutical companies, PDPs focus on either a single disease category or in some cases set of disease categories and second the PDPs function as 'virtual R\&D organizations' (Nisar and Hayter, 2017; Moran et al., 2014; Munoz et al., 2015; Grace, 2010), wherein most of the R\&D activities are outsourced to partner organizations. The focus, orientation and organization of PDPs is underpinned by the drive to keep the R\&D and operating cost down. Munoz et al., (2015) note, "while PDPs have to cover the cost of the 
product development and take into account the costs of product delivery (including registration cost), PDPs are aware that they need to stay as close as possible to the marginal cost of production to meet their access goals" (p.322). In this backdrop, outsourcing of R\&D activities is a central strategy PDPs adopt to achieve the objectives. In a broad context, outsourcing is not uncommon in the (bio) pharmaceutical industry (see for instance Howells et al., 2008; Lowman et al., 2012; Schuhmacher et al., 2016) and in fact, countries such as India in particular, has emerged as one of the key locations that have benefitted from this phenomenon (see for instance Mohiuddin et al., 2017). Therefore, unlike the relationship between the PDP and its funders, where the funders tend to have an upper hand, the relationship between the PDP and its operational partners is skewed in favour of the PDPs.

Two questions are central to the question of outsourcing of R\&D activities. First question pertains to identification and selection of a reliable partners to undertake different activities in the drug development process and in this context reputation and trust in the competence and capabilities of the partners (Das and Teng, 1998; Zaheer and Harris, 2006), particularly in the case of using of contract research organisational and contract manufacturing organisations. Munoz et al. (2015) note that PDPs tend to enter into operational relationship with partners with whom either the project managers or senior managers have had experience of working with. This aspect in essence supports the assertion that trust relationship formed through prior history or interaction between organizations and key boundary spanners influence formation of partnerships between organizations (Gulati and Sytch, 2009; Gulati et al., 2012). And second question relate to structuring of these relationships. Seen through the lens of resource dependence perspective, the type of governance mechanism partners enters into, particularly in such types of buyer - supplier relationships, depends on dependency between the two parties, criticality of the resources, and the power difference between both the partners in the relationship (Handfield, 1993; Fink et al. 2006 Extant literature on collaborative relationships in high technology industry setting suggest that contractual agreements, instead of equity structures, are considered as preferred governance mechanism in such relationships (see Narula and Hagedroon, 1999; Roijakkers and Hagedoorn, 2006). Although in respect to identification, selection, negotiation and management of the collaborations with the partners, the project managers play central role, there is less insights on the nature of contractual agreements that exist between the PDPs and their operational partners. In this backdrop, critical issues relating to the implications of asymmetrical relation between the PDPs and their 
operational partners, particularly academic institutions, needs deeper examination (Munoz et al., 2015).

\section{Conclusions}

In the context of the global heath innovation ecosystem, the PDPs have emerged to play the role of system integrators, who primarily bring together resources, knowledge and expertise residing in various stakeholders in the ecosystem to develop solutions, particularly for neglected diseases. Most PDPs function on a non-profit basis, and lack financial capital and proprietary knowledge base to undertake R\&D activities to develop new drugs (Chataway et al., 2007; Munoz et al., 2015). Hence, their core capabilities are their relational capital prowess, through forming relationships, with the donors / funders on the one hand and with multiple partners who contribute their intellectual capital to undertake operational activities on the other hand, and this underpins PDPs role in the global health ecosystem. Considering the complex relationships, the PDPs establish with two different set of actors / stakeholders in the innovation ecosystem, it is imperative that success and survival of PDPs depends on their capabilities to manage the differing nature and orientation of power relations, governance mechanisms and trust that underpin the relationships PDPs enter into. Since their emergence, PDPs have shown to contribute to develop and create a pipeline of new solutions.

Notwithstanding the centrality of PDPs in the development of new drugs and other solutions for neglected diseases, from strategic management and organizational perspective, we identified a gap in understanding the complex functioning of these phenomenon. In this paper we attempt to plug this gap, and do so by using the resource dependence perspective, wherein we have attempted to discern and examine the nature of relationships between the PDPs and their funders and donors on one hand and between the PDPs and their operational partners on the other. We note that in their relationship with the PDPs, the donors, particularly the private donors have an upper hand often determining how the funding would be used by attaching various conditions as well as adopting different approaches to evaluate the performance of the PDPs (power and trust challenges). In contrast, the relationship between the PDPs and their operational partners, which primarily comprise of contract research organisation, contract manufacturing organisations and numerous research institutes, is skewed towards the PDPs (governance challenges). However, the nuances underpinning the relationships between PDPs and the funders and donors as well as between the PDPs and the 
operational partners are still hazy, though we have made an attempt in this paper to make things clearer and unbundle the complexities that exist in these relationships.

We conclude our assessment by identifying the key success factors to be managing power, trust and governance challenges. We dig into past PDPs (for AIDS, TB and Malaria, disease categories where most PDPs have distinct presence) and formation of existing PDPs in the context of the prevailing Novel Coronavirus epidemic, and conclude by calling for the need for more focus / research on the two sets of relationships that the PDPs form and manage to develop new drugs and solutions.

\section{References}

Aerts, C., Sunyoto, T., Tediosi, F., \& Sicuri, E. (2017). Are public-private partnerships the solution to tackle neglected tropical diseases? A systematic review of the literature. Health Policy, 121, 745-754.

Albertini, S. and J. Butler (1995). R\&D Networks in a Pharmaceutical Company: Some Implications for Human Resource Management. R\&D Management, 25, 377-393.

Aldrich, H. (1976). Resource dependence and interorganizational relations: Local employment service offices and social services sector organizations. Administration and Society, 7, 419-54.

Almeida, P., Hohberger, J. \& Parada, P. (2011). Individual scientific collaborations and firm-level innovation, Industrial and Corporate Change, 20, 1571-1599.

Arino, A., de la Torre, J., \& Ring, P. S. (2005). Relational quality and inter-personal trust in strategic alliances. European Management Review, 2, 15-27.

Asokan, G. V., \& Kasimanickam, R. K. (2013). Emerging Infectious Diseases, Antimicrobial Resistance and Millennium Development Goals: Resolving the Challenges through One Health. Central Asian journal of global health, 2, 76.

Bachmann, R., \& Inkpen, A. C. (2011). Understanding institutional-based trust building processes in inter-organizational relationships. Organization Studies, 32, 281-301.

Bartlett, C. A., and Ghoshal, S. (1990). Managing Across Borders: The Transnational Solution. Boston, Massachusetts: Harvard Business School Press.

Beamish, P., \& Berdrow, I. (2003). Learning from IJVs: The Unintended Outcome. Long Range Planning, 36, 285-303.

Bidault, F., \& Jarillo, C. J. (1997). Trust in economic transactions. In F. Bidault., P-Y. Gomez., \& G. Marion (Eds.), Trust: Firm and Society. Paris: Editions ESKA.

Bio Ventures for Global Health (2012). Bringing innovation to neglected disease research and development: Biotechnology Industry Organization (BIO).

Birgand, G., Castro-Sánchez, E., Hansen, S., Gastmeier, P., Lucet, J. C., Ferlie, E., ... \& Ahmad, R. (2018). Comparison of governance approaches for the control of antimicrobial resistance: Analysis of three European countries. Antimicrobial Resistance \& Infection Control, 7, 28.

Bloom, D. E., Black, S., \& Rappuoli, R. (2017). Emerging infectious diseases: a proactive approach. Proceedings of the National Academy of Sciences, 201701410.

Bovaird, T. (2004). Public-Private Partnerships: from Contested Concepts to Prevalent 
Practice. International Review of Administrative Sciences, 70, 199-215.

Brinkerhoff, D. W. and Brinkerhoff, J. M. (2011), Public-private partnerships: Perspectives on purposes, publicness, and good governance. Public Administration and Development, 31, 2-14.

Brooks AD, WA Wells, TD McLean, R Khanna, R Coghlan T Mertenskoetter, LA Privordumm, A Krattiger and RT Mahoney (2010). Ensuring that Developing Countries have Access to New Healthcare Products: The Role of Product Development Partnerships. Innovation Strategy Today, 3, 1-5.

Buse, K., and Waxman, A. (2001). Public-private health partnerships: a strategy for WHO, Bulletin of the World Health Organization: the International Journal of Public Health, 79, 748-754.

Casciaro, T., \& Piskorski, M. J. (2005). Power imbalance, mutual dependence, and constraint absorption: a closer look at resource dependence theory. Administrative Science Quarterly, 50, 167-199.

Chataway, J., Hanlin, R., Mugwagwa, J. and Muraguri, L., (2010). Global health social technologies: Reflections on evolving theories and landscapes. Research Policy, 39, 1277-1288

Chataway, J., Brusoni, S., Cacciatori, E., Hanin, R. et al. (2007). The International AIDS Vaccine Initiative (IAVI) in a changing landscape of vaccine development: A publicprivate partnership as knowledge broker and integrator, European Journal of Development Research, 19, 100-17.

Choi, J., \& Contractor, F. J. (2016). Choosing an appropriate alliance governance mode: The role of institutional, cultural and geographical distance in international research \& development (R\&D) collaborations. Journal of International Business Studies, 47, 210-232.

Clarke, A., \& MacDonald, A. (2019). Outcomes to Partners in Multi-Stakeholder Cross-Sector Partnerships: A Resource-Based View. Business \& Society, 58, 298-332.

Cooke, P. (2005). Rational drug design, the knowledge value chain and bioscience mega centres. Cambridge Journal of Economics, 29, 325-341.

Craft, J. C. (2008). Challenges facing drug development for malaria. Current opinion in microbiology, 11, 428-433.

Dalpe, R. (2003). Interaction between public research organizations and industry in biotechnology. Managerial Decision and Economics, 24, 171-185.

Dare, L. (2003). WHO and the challenges of the next decade. The Lancet, 361.

Das, T. K., \& Teng, B.-S. (2000). Instabilities of strategic alliances: An internal tensions perspective. Organization Science, 11, 77-101

Dicken, P. (1994). Global-local tensions: Firms and states in the global space-economy. Advances in Strategic Management, 10, 217-247.

Doz, Y., \& Hamel, G. (1998). Alliance advantage: The art of creating value through partnering. Boston, MA: Harvard Business School Press.

Doz, Y. L., Olk, P. M., \& Ring, P. S. (2000). Formation processes of R\&D consortia: Which path to take? Where does it lead? Strategic Management Journal, 21, 239-66

Drees, J. M., \& Heugens, P. P. (2013). Synthesizing and extending resource dependence theory: a meta-analysis. Journal of Management, 39, 1666-1698.

De Jong, G. \& Woolthuis, K. (2008). The institutional arrangements of innovation: Antecedents and Performance effects of trust in high-tech alliances. Industry and Innovation, 15, 45-67

de Rond, M., \& Bouchikhi, H. (2004). On the dialectics of strategic alliances. Organization 
Science, 15, 56-69.

de Vrueh, R. L., \& Crommelin, D. J. (2017). Reflections on the future of pharmaceutical publicprivate partnerships: from input to impact. Pharmaceutical research, 34, 1985-1999.

Fink, R.C., Edelman, L.F., Hatten, K.J. and James, W.L. (2006): Transaction cost economics, resource dependence theory, and customer-supplier relationships, Industrial and Corporate Change, 15(3): 497-529.

Gargiulo, M. 1993 "Two-step leverage: Managing constraint in organizational politics". Administrative Science Quarterly, 38: 1-19

Gallouj F., Rubalcaba L. Windrum P. (2013), Public Private Innovation Networks in Services, Edward Elgar.

Gereffi, G. (1994). Commodity Chains and Global Capitalism. Westport, CT: Greenwood Press.

Ghosal, S. and C. A. Bartlett (1993). The Multinational Company as an Inter-Organizational Network. In: S. Ghosal and D. E. Westney (eds), Organization Theory and Multinational Companies. St Martins Press, New York.

Giauque, D. (2009) The difficulties of managing public-private partnerships in Europe. Revue française d'administration publique, 130, 383-394.

Giunta, A., Pericoli, F. M., \& Pierucci, E. (2016). University-industry collaboration in the biopharmaceuticals: The Italian case. The Journal of Technology Transfer, 41, 818840.

Global Risk Report (2018). World Economic Forum. Geneva.

Granot, H. (1997). Emergency inter-organizational relationships. Disaster Prevention and Management: An International Journal, 6, 305-310.

Grace, C., \& Britain, G. (2010). Product development partnerships (PDPs): lessons from PDPs established to develop new health technologies for neglected diseases. London: Great Britain, Department for International Development, Human Development Resource Centre.

Global Risks Report (2013), An Initiative of the Risk Response Network, World Economic Forum, Geneva.

Global Risks Report (2018), Insight Report, World Economic Forum, Geneva.

Goerzen, A. (2007). Alliance networks and firm performance: The impact of repeated partnerships. Strategic Management Journal, 28, 487-509.

Gulati, R. (1998). Alliances and networks. Strategic Management Journal, 19, 293-317.

Gulati, R. and Sytch, M. (2008). Does familiarity breed trust? Revisiting the antecedents of trust. Managerial and Decision Economics, 29: 165-190

Gulati, R., Wohlgezogen, F. \& Zhelyazkov, P. (2012). The Two Facets of Collaboration: Cooperation and Coordination in Strategic Alliances, The Academy of Management Annals, 6:1, 531-583.

Gustavsen, K., \& Hanson, C. (2009). Progress in public-private partnerships to fight neglected diseases. Health Affairs, 28, 1745-1749.

Handfield, R. B. (1993): A resource dependence perspective of Just-in-Time purchasing, Journal of Operations Management, 11: 289-311

Hagedoorn, J. (2002). Inter-firm R\&D partnerships: An overview of major trends and patterns since 1960. Research Policy, 31, 477-492.

Hagedoorn, J., \& Narula, R. (1996). Choosing modes of governance for strategic technology partnering: International sectoral differences International Journal of Business Studies, 265-284. 
Hennart, J.-F. (1988). A transaction costs theory of equity joint ventures. Strategic Management Journal, 9, 361-374.

Hillman, A. J., Withers, M. C., \& Collins, B. J. (2009). Resource dependence theory: a review. Journal of Management, 35, 1404-1427.

Hodge, G. Carsten G., and Biygautane, M (2018) Do PPP's work? What and how have we been learning so far? Public Management Review, 20:8, 1105-1121.

Howells, J., Gagliardi, D. and Malik, K. (2008). The growth and management of R\&D outsourcing: evidence from UK pharmaceuticals. R\&D Management, 38: 205-219.

Hsueh, P. R., Chen, W. H., \& Luh, K. T. (2005). Relationships between antimicrobial use and antimicrobial resistance in Gram-negative bacteria causing nosocomial infections from 1991-2003 at a university hospital in Taiwan. International journal of antimicrobial agents, 26, 463-472.

Hui, D. S. C., Chan, M. C. H., Wu, A. K., \& Ng, P. C. (2004). Severe acute respiratory Syndrome (SARS): epidemiology and clinical features. Postgraduate medical journal, 80, 373-381.

Inkpen, A. C., \& Currall, S. C. (2004). The co-evolution of trust, control, and learning in joint ventures. Organization Science, 15, 586-599.

IDRC (2013). Value for Money discourse: Risks and opportunities for R4D. http://www.idrc.ca/EN/Documents/Value-for-Money-Partnership-Practices-3.pdf (accessed Jan 20, 2020).

Jakobsen PH, Wang MW, Nwaka S (2011) Innovative Partnerships for Drug Discovery against Neglected Diseases. PLOS Neglected Tropical Diseases 5(9): e1221.

Jones, O. (2000). Innovation management as a post-modern phenomenon: the outsourcing of pharmaceutical R\&D. British Journal of Management, 11, 341-356.

Jones, K. E., Patel, N. G., Levy, M. A., Storeygard, A., Balk, D., Gittleman, J. L., \& Daszak, P. (2008). Global trends in emerging infectious diseases. Nature, 451(7181), 990.

Kim, J. W., \& Higgins, M. C. (2007). Where do alliances come from? The effect of upper echelons on alliance formation Research Policy, 36, 499-514.

Kim, Y., \& Cannella, A. A. (2008). Toward a social capital theory of director selection . Corporate Governance: An International Review, 16(4), 282-293

Klitsie, E.J., Ansari, S. \& Volberda, H.W. (2018). Maintenance of Cross-Sector Partnerships: The Role of Frames in Sustained Collaboration. Journal of Business Ethics. 150, 401423.

Kogut, B. (1988). Joint ventures: Theoretical and empirical perspectives. Strategic Management Journal, 9, 319-332.

Kouadio, I. K., Aljunid, S., Kamigaki, T., Hammad, K., \& Oshitani, H. (2012). Infectious diseases following natural disasters: prevention and control measures. Expert review of anti-infective therapy, 10, 95-104.

Krishnan, R., Martin, X., \& Noorderhaven, N. G. (2006). When does trust matter to alliance performance? Academy of Management Journal, 49, 894-917.

Lang, T; Greenwood, B; (2003) The development of Lapdap, an affordable new treatment for malaria. The Lancet infectious diseases, 3, 162-168.

Laxminarayan, R., Duse, A., Wattal, C., Zaidi, A. K., Wertheim, H. F., Sumpradit, N., ... \& Greko, C. (2013). Antibiotic resistance - the need for global solutions. The Lancet infectious diseases, 13, 1057-1098.

Lee, J. W., \& McKibbin, W. J. (2004). Globalization and disease: the case of SARS. Asian Economic Papers, 3, 113-131. 
Levin, D., Cross, R. (2004). The strength of weak ties you can trust: The mediating role of trust in effective knowledge transfer. Management Science, 50: 1477-1490.

Lezaun, J., \& Montgomery, C. M. (2015). The Pharmaceutical Commons: Sharing and Exclusion in Global Health Drug Development. Science, Technology, \& Human Values, 40, 3-29.

Lo, N. C., Addiss, D. G., Hotez, P. J., King, C. H., Stothard, J. R., Evans, D. S., ... \& Raso, G. (2017). A call to strengthen the global strategy against schistosomiasis and soiltransmitted helminthiasis: the time is now. The Lancet infectious diseases, 17, e64-e69.

Looney W. (2011). The Power of Product Development Partnerships. Pharmaceutical Executive. http://www.pharmexec.com/pharmexec/article/articleDetail.jsp?id=739264 (accessed on July 10, 2019).

Lowman, M., Trott, P., Hoecht, A., and Sellam, Z. (2012). Innovation risks of outsourcing in pharmaceutical new product development, Technovation, 32(2): 99-109.

Lumineau, F., Quélin, B. V. (2012). An Empirical Investigation of Interorganizational Opportunism and Contracting Mechanisms, Strategic Organization, 10(1): 55-84.

Lui, S. S., Ngo, H.-Y. 2004. The role of trust and contractual safeguards on cooperation in non-equity alliances. Journal of Management, 30, 471-485.

Lynall, M. D., Golden, B. R., \& Hillman, A. J. (2003). Board composition from adolescence to maturity: A multitheoretic view. Academy of Management Review, 28(3), 416431.

Mahmoud, A., Danzon, P. M., Barton, J. H., \& Mugerwa, R. D. (2006). Product development priorities. Disease control priorities in developing countries, 139-156.

McQuaid, R. (2000). The theory of partnership: why have partnerships? in S. P. Osborne (ed.), Public-Private Partnerships: theory and practice in international perspective. London: Routledge

Mohr, J., Spekman, R. (1994). Characteristics of partnership success: Partnership attributes, communication, behaviour and conflict resolution techniques. Strategic Management Journal, 15, 135-152.

Mohiuddin, M., Nurul, M., Mazumder, H., Chrysostome, E., and Su, Z. (2017). Relocating high-tech industries to emerging markets: case of pharmaceutical industry outsourcing to India, Transnational Corporations Review, 9(3), 201-217

Moran, M. (2005). A breakthrough in R\&D for neglected diseases: new ways to get the drugs we need. PLoS medicine, 2, e302.

Moran M, Guzman J, Ropars A-L, McDonald A, Jameson N, Omune B. (2009) Neglected Disease Research and Development: How Much Are We Really Spending? PLoS Med 6(2): e1000030.

Moran, M., Guzman, J., Ropars, A. L., \& Illmer, A. (2010). The role of Product Development Partnerships in research and development for neglected diseases. International Health, 2(2), 114-122.

Moran, M., \& Stevenson, M. (2013). Illumination and innovation: What philanthropic foundations bring to global health governance. Global Society, 27, 117-137.

Muñoz, V., Visentin, F., Foray, D., \& Gaulé, P. (2014). Can medical products be developed on a non-profit basis? Exploring product development partnerships for neglected diseases. Science and Public Policy, 42, 315-338.

Muthusamy, S. K., White, M.A. (2005). Learning and Knowledge Transfer in Strategic Alliances: A Social Exchange View. Organization Studies, 26, 415-440.

Nakatani, H. (2016). Global Strategies for the Prevention and Control of Infectious Diseases 
and Non-Communicable Diseases. Journal of epidemiology, 26, 171-178.

Nambiar, S., Laessig, K., Toerner, J., Farley, J. and Cox, E. (2014), Antibacterial Drug Development: Challenges, Recent Developments, and Future Considerations. Clinical Pharmacology \& Therapeutics, 96, 147-149.

Narula, R., \& Dunning, J. (1998). Explaining international R and D alliances and the role of governments. International Business Review, 7, 377-397.

Narula, R., \& Hagedoorn, J. 1999. Innovating through strategic alliances: moving towards international partnerships and contractual agreements. Technovation, 19(5): 283-294.

Nicholls-Nixon, C. L., \& Woo, C. Y. (2003). Technology sourcing and output of established firms in a regime encompassing technological change. Strategic Management Journal, 24, 651-666.

North D. C. (1993). Institutions and credible commitment. Journal of Institutional and Theoretical Economics, 149, 11-23.

Nwaka, S., \& Ridley, R. G. (2003). Science \& society: Virtual drug discovery and development for neglected diseases through public-private partnerships. Nature Reviews Drug Discovery, 2(11), 919.

Odagiri, H. (2003). Transaction costs and capabilities as determinants of the R\&D boundaries of the firms: A case of the ten largest pharmaceutical firms in Japan. Managerial Decision and Economics, 24, 187-211.

Oliver, C. (1990). Determinants of Interorganizational Relationships: Integration and Future Directions. Academy of Management Review, 15, 241-65.

Papaioannou, T., Wield, D., and Chataway, J. (2009). Knowledge ecologies and ecosystems? An empirically grounded reflection on recent developments in innovation systems theory. Environment and Planning C: Government and Policy, 27, 319-339.

Parkhe, A. (1993). Strategic alliance structuring: a game theoretic and transaction cost examination of inter-firm co-operation. Academy of Management Journal, 36, 794-829.

Parkinson, A. J., \& Butler, J. C. (2005). Potential impacts of climate change on infectious diseases in the Arctic. International Journal of Circumpolar Health, 64, 478-486.

Parmigiani, A., \& Rivera-Santos, M. (2011). Clearing a Path Through the Forest: A MetaReview of Interorganizational Relationships. Journal of Management, 37, 1108-1136.

Patnaik, S. (2011). Inter-organisational collaborations as embedded social systems: A critical realist explanation of alliance evolution. Unpublished doctoral thesis, University of Liverpool.

Patnaik, S., Pereira, V., Malik, A., Temouri, Y., Roohanifar, M. (2019). The Dance of Power and Trust- Exploring Micro-Foundational Dimensions in the Development of Global Health Partnership. British Academy of Management conference proceeding.

Pedrique, B., Strub-Wourgaft, N., Some, C., Olliaro, P., Trouiller, P., Ford, N., ... \& Bradol, J. H. (2013). The drug and vaccine landscape for neglected diseases (2000-11): a systematic assessment. The Lancet Global Health, 1, 371-379.

Pereira, V., Munjal, S., and Ishizaka, A. (2019). Outsourcing and Offshoring Decision Making and its Implications for Businesses- A Synthesis of Research Pursuing Five Pertinent Questions. Journal of Business Research. 103, 348-355.

Pfeffer, J., \& Nowak, P. (1976). Joint ventures and interorganizational interdependence. Administrative Science Quarterly, 21, 398-418.

Poppo, L., Zenger, T. (2002). Do formal contracts and relational governance function as substitute or complements? Strategic Management Journal, 23, 707-725.

Powell, W. W., K. W. Koput and L. Smith-Doerr (1996). Interorganizational Collaboration 
and the Locus of Innovation: Networks of Learning in Biotechnology, Administrative Science Quarterly, 41, 116-145.

Pratt, B and Loff, B. (2012). Contribution of product development partnerships to access to medicines and research capacity strengthening. The Lancet, 380(2).

Reich, M. (eds) (2002). Public-private partnerships for public health. Cambridge: Harvard Centre for Population and Development Studies.

Ridley, R. G. (2001). Putting the Partnership into public-private partnerships, Bulletin of the World Health Organization: the International Journal of Public Health, 79, 694.

Ring, P. S., \& Van de Ven, A. H. (1994). Developmental processes of cooperative interorganizational relationships. Academy of Management Review, 19, 90-118.

Roijakkers, N., \& Hagedoorn, J. (2006). Inter-firm R\&D partnering in pharmaceutical biotechnology since 1975: Trends, patterns, and networks. Research Policy, 35, 431446.

Rondinelli, D. A., \& London, T. (2003). How corporations and environmental groups cooperate: assessing cross-sector alliances and collaborations. Academy of Management Executive, 17, 61-76.

Rothaermel, F. T., Boeker, W. (2007). Old technology meets new technology: Complementarities, similarities, and alliance formation Strategic Management Journal, 28, 47-77.

Rothaermel, F. T. and Deeds, D. L. (2004), Exploration and exploitation alliances in biotechnology: a system of new product development. Strategic Management Journal 25, 201-221.

Rousseau, D. M., Sitkin, S. B., Burt, R. S., Camerer, C. (1998) "Not So Different after All: A Cross-Discipline View of Trust," Academy of Management Review. 23(3): 393-404.

Ruckert, A., \& Labonté, R. (2014). Public-private partnerships (ppps) in global health: the good, the bad and the ugly. Third World Quarterly, 35, 1598-1614.

Sadowski, B., Duysters, G. (2008). Strategic technology alliance termination: An empirical investigation. J. Eng. Technol. Management., 25, 305-320.

Sands, P., Mundaca-Shah, C., \& Dzau, V. J. (2016). The neglected dimension of global security - a framework for countering infectious-disease crises. New England Journal of Medicine, 374, 1281-1287.

Santoro, M. D., \& McGill, J. P. (2005). The effect of uncertainty and assets co-specialization on governance in biotechnology alliances Strategic Management Journal, 26, 12611269.

Selsky, J. W., \& Parker, B. (2005). Cross-sector partnerships to address social issues: Challenges to theory and practice. Journal of Management, 31, 849-73.

Silver, L. L. (2011). Challenges of antibacterial discovery. Clinical microbiology reviews, 24, 71-109.

Spekman, R. E., Forbes, T. M., Isabella, L. A., \& MacAvoy, T. C. (1998). Alliance management: A view from the past and a look into the future. Journal of Management Studies, 35, 747-772.

Stankiewicz, R. (1997). The Development of Beta Blockers at Astra-Hässle and the Technological System of the Swedish Pharmaceutical Industry, Technological Systems and Industrial Dynamics, 5, 93-137.

Tatem, A. J., Rogers, D. J., \& Hay, S. I. (2006). Global transport networks and infectious disease spread. Advances in parasitology, 62, 293-343. 
Trouiller, P., Olliaro, P., Torreele, E., Orbinski, J., Laing, R., and Ford, N. (2002). Drug development for neglected diseases: a deficient market and a public-health policy failure. 10.4324/9781315254227-22.

Vakili, K., \& McGahan, A. M. (2016). Health care's grand challenge: Stimulating basic science on diseases that primarily afflict the poor. Academy of Management Journal, 59, 1917 1939.

Van Ham, H., \& Koppenjan, J. (2001). Building Public-Private Partnerships: Assessing and managing risks in port development. Public Management Review, 3, 593-616.

Varda, D., Shoup, J. A., \& Miller, S. (2012). A systematic review of collaboration and network research in the public affairs literature: implications for public health practice and research. American journal of public health, 102, 564-71.

Vecchi, V., \& Hellowell, M. (Eds.). (2018). Public-Private Partnerships in Health: Improving Infrastructure and Technology. Springer.

Vlaar, P. W. L., Van Den Bosch, F. A. J., \& Volberda, H. W. (2007). On the evolution of trust, distrust, and formal coordination and control in interorganizational relationships: Toward an integrative framework. Group and Organization Management, 32, 407-431.

Whittaker, E. and Bower, D. J. (1994), A shift to external alliances for product development in the pharmaceutical industry. R\&D Management, 24, 249-260.

World Health Organization (2006) Public Health-Innovation and Intellectual Property Rights: Report of the Commission on Intellectual Property Rights, Innovation and Public Health. Geneva: World Health Organization

World Health Organization (2015). Trade, foreign policy, diplomacy and health: Publicprivate partnerships for health. Geneva: World Health Organization

World Health Organization (2018). https://www.who.int/antimicrobial-resistance/en/

Wettenhall, R. (2003). The Rhetoric and Reality of Public-Private Partnerships", Public Organization Review, 3, 77-107.

Widdus, R. (2001). Public-private partnerships for health: their main targets, their diversity, and their future directions. Bulletin of the World Health Organization, 79, 713-720.

Woodson, T. S. (2016). Public private partnerships and emerging technologies: A look at nanomedicine for diseases of poverty. Research Policy, 45, 1410-1418.

Yang, P., Chen, Y., Jiang, S., Shen, P., Lu, X., \& Xiao, Y. (2018). Association between antibiotic consumption and the rate of carbapenem-resistant Gram-negative bacteria from China based on 153 tertiary hospitals data in 2014. Antimicrobial Resistance \& Infection Control, 7, 137.

Ybarra, C. E., \& Turk, T. A. (2009). The evolution of trust in information technology alliances. Journal of High Technology Management Research, 20, 62-74.

Zaheer, A., McEvily, B., \& Perrone, V. (1998). Does trust matter? Exploring the effects of inter-organizational and inter-personal trust on performance. Organization Science, 9, 141-159.

Zaheer, A., Harris, J. (2006) “Interorganizational Trust,” in Shenkar, O., Reuer, J. J. (eds) Handbook of Strategic Alliances, pp. 169-97. Thousand Oaks, CA: Sage.

Zahra, S.A., Filatotchev, I., \& Wright, M. (2009). How do threshold firms sustain corporate entrepreneurship? The role of boards and absorptive capacity. Journal of Business Venturing, 24(3), 248-260

Zorzet A. (2014). Overcoming scientific and structural bottlenecks in antibacterial discovery and development. Upsala journal of medical sciences, 119, 170-5.

Zucker, L. G., \& Darby, M. R. (1997). Present at the biotechnological revolution: 
Transformation of technological identify for large incumbent pharmaceutical firm. Research Policy, 26, 429-446. 